\title{
4
}

\section{Who gets what, when and how: The politics of resource allocation to parliamentary parties}

\section{Yvonne Murphy}

People don't like their politicians to be comfortable. They don't like you having expenses. They don't like you being paid. They'd rather you lived in a ... cave. $^{1}$

While the source of this declaration is the bad-tempered fictional government press secretary Malcolm Tucker, as portrayed in the BBC's The Thick of It, it would be difficult to find a more apt way to describe the general public sentiment that surrounds the topic of politicians' salaries and allowances. Any mention of the subject is generally met with cynicism, suspicion and, often, a sense of outrage - a state of affairs that is not aided by periodic scandals concerning misconduct over claims for expenses. Understandably, recent decades have seen an increasing public appetite for closer scrutiny, increased transparency and more effective oversight of how public monies are spent on politicians and political parties-including calls from politicians themselves. And, since the 1970s, there has been a shift in Australia towards addressing such calls through the establishment of bodies 
such as the Commonwealth Remuneration Tribunal and periodic audits to review, report on and offer recommendations on the regularisation of such spending. ${ }^{2}$

Yet one set of taxpayer-funded allowances has consistently escaped the gaze of such reviews and has received little attention from scholars: the staffing, office space and information and communication technology (ICT) equipment provided to qualifying parliamentary parties to facilitate them in organising and supporting their members and working with government and other parties to coordinate parliamentary business. Existing scholarship has examined the provision of resources to individual parliamentarians and parties in terms of its effect on both intraparty and interparty dynamics and in facilitating the professionalisation of politics. ${ }^{3}$ For example, studies of the public financing of political parties have explored the impact of this funding on public attitudes to politics, party behaviour and the relationship between parties and the state (see chapters 1 and 6, this volume). ${ }^{4}$ Nevertheless, scholars have not systematically examined the direct provision of resources to legislative parties with regard to either Australia or other jurisdictions. This is also true of the impact that such resource provision has on intra-parliamentary dynamics.

This is not really surprising, given that resources of this sort tend to be distributed on a discretionary basis and such in-house decisionmaking limits visibility. They are little discussed, even among parliamentarians, with many taking for granted the presence or absence of party-based support services. Moreover, apart from the work of Norm Kelly, these facilities and resources are little talked about in terms of their impact on democratic representation - that is,

2 See, for example, Cathy Madden (2015) 'Parliamentary Entitlements: Inquiries and Reports', Flagpost, 10 August, Canberra: Parliamentary Library, available at: aph.gov.au/About_Parliament/ Parliamentary_Departments/Parliamentary_Library/FlagPost/2015/August/Entitlements.

3 Nicole Bolleyer and Anika Gauja (2011) 'Parliamentary Salaries as a Party Resource: Party Organizational Power in Westminster Democracies', Party Politics 19(5): 778-97; Richard S. Katz and Peter Mair (1995) 'Changing Models of Party Organization and Party Democracy: The Emergence of the Cartel Party', Party Politics 1(1): 5-28; Kate Jones (2006) 'One Step at a Time: Australian Parliamentarians, Professionalism and the Need for Staff', Parliamentary Affairs 59(4): 638-53.

4 Fernando Casal Bertoa, Fransje Molenaar, Daniela R. Piccio and Ekaterina R. Rashkova (2014) 'The World Upside Down: Delegitimising Political Finance Regulation', International Political Science Review 35(3): 355-75; Ingrid van Biezen (2004) 'Political Parties as Public Utilities', Party Politics 10(6): 701-22; Katz and Mair, 'Changing Models of Party Organization and Party Democracy'. 
how they impact on the capacity of members and legislative parties to participate effectively in the functions of parliament. ${ }^{5}$ This is perhaps a symptom of the fact that they fall into the cracks between electoral funding, wider party financing and parliamentary resource provision for individual members. Qualification criteria for the allocation of resources tend to vary from legislature to legislature - as highlighted in Kelly's Democratic Audit of Australia Discussion Paper ranging from provision being made for individual Independents at the federal level to a parliamentary party qualification threshold of 11 parliamentarians in the Victorian State legislature. To the extent that we cannot depend on uniform standards or statutory provisions to inform us of who gets what, when and how, parliamentary allowances for staff, office space and ICT constitute a somewhat 'invisible' form of state support for the parliamentary wing of political parties.

A systemic examination of resources allocated to parliamentary parties is therefore overdue. We need to better understand how legislative parties operate, how this is supported within the parliamentary system by the provision of these resources and what consequences this might have for representative democracy. This chapter addresses these issues in several sections. The first examines the history of the provision of parliamentary resources in Australia and places them in an international context. The second sets out the distinctions between 'tools of the trade' parliamentary party allowances (covering staffing, office space and so on) and others found within the Australian political system. This is then followed by analysis of how allowances are allocated and overseen in the Australian context and the role of discretion and bargaining in the process. The chapter concludes with a brief consideration of some of the democratic implications of the present system of parliamentary party resource allocation.

Analysis is based on qualitative data gathered on the practices surrounding parliamentary party resource provision in Australian parliaments, with particular emphasis on the Federal Parliament. Data consist of first-hand accounts by serving and former parliamentarians gathered through parliamentary debates, official

5 See Norm Kelly (2004) Determining Parliamentary Parties: A Real Status Symbol, Democratic Audit of Australia Discussion Paper, Melbourne: Australian Policy Online, available at: apo.org. $\mathrm{au} /$ node $/ 585$.

6 ibid. 
statements and media interviews. Similarly, documentary evidence of resource allocation practices has been gathered from online parliamentary repositories, formal reviews of allowance frameworks conducted by bodies such as review committees and remuneration tribunals and statements by parliamentarians, government ministers and spokespeople. This approach was required because of the lack of formal guidelines governing the allocation of parliamentary party resources and the lack of formal review mechanisms. As will be shown, this is an area of parliamentary life ruled by convention rather than formal regulation, discretion rather than certainty and backroom negotiations rather than transparency.

\section{The historical origins and expansion of parliamentary allowances}

As noted by Gauja and Sawer in Chapter 1, there have been increasing moves towards the regulation of political parties in Australia since the 1980s, not least due to the introduction of new and increasing levels of state subventions. Financial support for politics - in the form of payments to politicians - is not, however, a new phenomenon. In the United Kingdom, it dates back as far as the thirteenth century when shires and boroughs made payments to Members of Parliament (MPs) - a practice that continued until the late seventeenth century. ${ }^{7}$ The US Congress employed a similar system until standardised per diem and eventually per annum salaries were introduced in 1789 and 1815, respectively. ${ }^{8}$ The introduction of payments such as those in the United States was intended to limit financial dependence on vested interests and to bolster the capacity of members to engage in independent and nationally focused decision-making. This is an important point to note in relation to modern-day moves towards the standardisation and regulation of public subventions for political activity, the aim of which has been, inter alia, to insulate parliamentary actors from reliance on vested interests. France, Holland, Belgium, Sweden and Brazil followed suit by introducing annual salaries for politicians,

7 House of Commons Information Office (2009) Members' Pay, Pensions and Allowances, No. M5, London: House of Commons Information Office.

8 Ida A. Brudnick (2014) Salaries of Members of Congress: Recent Actions and Historical Tables, Washington, DC: US Congress. 
and Canada, New Zealand, Portugal and Norway adopted sitting day allowances, all of which occurred in the first half of the nineteenth century. It is within this broader international context that salary payments were first introduced for parliamentarians in Australia.

Payment for MPs and removal of existing property qualifications were two of the demands of the Chartist movement, and were seen as a prerequisite for working-class representation in parliament. The Parliament of Victoria led the way in introducing MPs' pay in $1870^{9}$ and, despite delays caused by opposition in conservative upper houses, the other Australian colonies followed suit during the 1880s and 1890s. A salary allowance was also introduced in the Commonwealth Parliament on its establishment in 1901. Yet, not everyone endorsed the measure. John Stuart Mill, for example, objected on the basis that it would encourage the emergence of a class of professional politician, interested only in money. ${ }^{10}$ The reality on the ground, in Westminster at least, was that the reward of public service was not the only motivating factor for many who aspired to win a seat in parliament in the nineteenth century. Salary allowances may not have existed, but substantial material rewards came in the form of lucrative pensions and appointments. Becoming a parliamentarian was, in fact, so desirable that many were willing to pay for the privilege. ${ }^{11}$ Therefore, while Mill's argument in favour of preserving the purity of public service was not without merit, it was undermined by the presence of indirectly administered material rewards that were controlled by private interests.

As noted in the Victorian debates, the alternative proposed by Mill was that representatives ought to be supported by contributions from their constituents. However, this approach had been tried, tested and rejected in the seventeenth and eighteenth centuries by Westminster and the US Congress, respectively, owing to the conflict of interest it created for members forced to decide between local and national interests. In 1909, the Osborne judgement in the United Kingdom

9 Kate Jones (2007) 'Daring and Discretion: Paying Australian Legislators', The Journal of Legislative Studies 13(2): 235-53; House of Commons Information Office (2004) Members' Pay, Pensions and Allowances, London: British House of Commons; Constitution of the Irish Free State (1922), Dublin: Stationery Office.

10 Marian Sawer (2001) 'Pacemakers for the World?', in Marian Sawer (ed.) Elections: Full, Free and Fair, Sydney: The Federation Press, p. 14.

11 House of Commons Information Office (2009), Members' Pay, Pensions and Allowances. 
rendered it illegal for trade unions to make payments to workingclass MPs - a practice that could be seen as analogous to constituency contributions. ${ }^{12}$

A positive effect of introducing salaries for parliamentarians was that it opened up the prospect of parliamentary participation from across the socioeconomic divide. Prior to the introduction of parliamentary salaries, those hailing from working-class backgrounds faced tremendous barriers to political involvement. For example, stonemason Charles Jardine Don, who was elected in 1859 in Victoria, had great difficulty combining parliamentary duties with earning a living. ${ }^{13}$

Owing to their origin as a modest form of support for individual MPs, and perhaps reflecting the elite/cadre model of party politics that prevailed in Australia until the 1890s, ${ }^{14}$ parliamentary allowances were initially provided exclusively to members without reference to their parliamentary parties. Despite the consolidation of the Australian party system over the course of the twentieth century, this form of individual allowance has persisted, increased and indeed expanded over the years. Initially introduced at $£ 400$ per annum in $1901,{ }^{15}$ salaries in the Commonwealth Parliament increased on an ad hoc basis according to 'no fixed pattern of approach' until the Remuneration Tribunal was established in $1973 .{ }^{16}$ Further changes included the introduction of an income tax-exempt electorate expense allowance in $1952 ;{ }^{17}$ the provision of subsidised printing, postage and home telephone calls and increased travel assistance in the 1960s, ${ }^{18}$ and expanded staffing and accommodation provisions in 1975.

12 Paul Seaward (2010) 'Sleaze, Old Corruption and Parliamentary Reform: An Historical Perspective on the Current Crisis', Political Quarterly 81(1): 39-48.

13 See the entry for Don, Charles Jardine (1820-1866) in S. Merrifield (1972) Australian Dictionary of Biography. Volume 4, Melbourne: Melbourne University Press, available at: adb.anu. edu.au/biography/don-charles-jardine-3423.

14 Katz and Mair, 'Changing Models of Party Organization and Party Democracy'; Peter Loveday, Allan W. Martin and Robert S. Parker (1977) The Emergence of the Australian Party System, Sydney: Hale \& Iremonger.

15 Jones, 'Daring and Discretion'.

16 Justice Kerr ['Kerr Report'] (1971) Salaries and Allowances of Members of the Parliament of the Commonwealth: A Report of Inquiry by Mr Justice Kerr, Canberra: Commonwealth Parliament of Australia.

17 ibid.

18 John Wilkinson (2002), MPs' Entitlements, Occasional Paper No. 8, Sydney: NSW Parliamentary Library Research Service. 
Since 2007, all Senators and MPs have also been allowed to hire four electorate staff, with the possibility of additional 'personal positions' being allocated on a discretionary basis.

A similar evolution of allowance structures can be found across Australia's State parliaments and, indeed, the parliaments of other jurisdictions. For example, the 1923 Irish parliamentarian received a salary 'allowance' of £30 per month and 'first class railway travelling facilities' to facilitate travel to and from parliamentary sittings. ${ }^{19}$ Over the years, this evolved into salary provisions comparable with those received by senior civil servants. The first-class railway travel facility has also been replaced with the Travel and Accommodation Allowance (TAA), calculated according to the distance of the MP's principal private residence from the National Parliament in Dublin. ${ }^{20}$ A suite of other allowances is also provided, such as mobile phone and postage allowances, staffing provisions and the Parliamentary Standard Allowance, which has a range of constituency-related uses, including the maintenance of a constituency office. ${ }^{21}$

In addition to these allowances supporting individual parliamentarians, support for parliamentary parties has also expanded in recent decades to include increased travel and staff allowances for office-holders. However, the significant leeway given to individual legislators in the deployment and use of their individual allowances allowed parliamentary parties to benefit from the general expansions seen in earlier decades. As highlighted by Bolleyer and Gauja, ${ }^{22}$ there is little in the way of regulatory deterrents to prevent practices such as the use of allowances for party political purposes. This issue came to prominence most recently in 2015 when Liberal Speaker of the House of Representatives Bronwyn Bishop used her parliamentary travel entitlements to attend a Liberal Party fundraiser. There is therefore substantial potential for intermingling between allowances paid to individual members and those paid to parliamentary parties, and this exacerbates the lack of transparency surrounding the extent and sources of allowances made available to parliamentary parties in

19 The Oireachtas (Payment of Members) Act (1923), Dublin: Stationery Office.

20 Parliamentary Standard Allowance (PSA) (2014), Dublin: Houses of the Oireachtas Commission, available at: oireachtas.ie/parliament/tdssenators/salariesallowances/.

21 ibid.

22 Nicole Bolleyer and Anika Gauja (2015) 'The Limits of Regulation: Indirect Party Access to State Resources in Australia and the United Kingdom', Governance 28(3): 321-40. 
particular. One such source that has received little scholarly attention up to this point is the 'tools of trade' category of allowances provided to parliamentary parties in their own right.

\section{Equipping parliamentary parties with the 'tools of trade'}

'Tools of trade' allowances are allocated to legislative parties in all of Australia's parliaments except the Northern Territory (NT) and the Australian Capital Territory (ACT). Where they are provided, they include staffing, office space, meeting space and additional travel allowances for office-holders; their purpose being to provide parties with the 'tools of trade' ${ }^{23}$ required to function effectively in the parliamentary setting. Australian legislative parties do not receive monetary support comparable with the provision of 'Short Money' in Westminster or the Parliamentary Activities Allowance (PAA) paid to party leaders in respect of their party's MPs and to Independents in the Irish Parliament. Therefore, it is not necessary to examine financial resources in the context of tools-of-trade resource provision in Australia, as the government does not provide direct funding to parliamentary parties. This simplifies matters somewhat.

Tools-of-trade allowances allocated to legislative parties can be distinguished from a similar suite of salary and tools-of-trade allowances provided directly to individual parliamentarians for their own direct use - that is, base salaries, salary top-ups for office-holders, individual electorate allowances and other benefits. It is important to note that the last category can and indeed has been used by or for the benefit of legislative parties. For example, Bolleyer and Gauja document the practice of salary tithing by parliamentary parties in their 2011 and 2015 studies. ${ }^{24}$ However, irrespective of the level of institutionalisation the practice attains, it constitutes a transaction between the parliamentarian and their party. The state provides a resource to the MP - their private salary in this case - and the MP then passes a portion on to the party. The transaction is therefore

23 Committee for the Review of Parliamentary Entitlements ['Belcher Review'] (2010) Review of Parliamentary Entitlements, Canberra: Parliament of Australia, p. 9.

24 Bolleyer and Gauja, 'Parliamentary Salaries as a Party Resource'; Bolleyer and Gauja, 'The Limits of Regulation'. 
between the parliamentarian and the party, not between the state and the party. This is also the case where an MP informally gifts a non-monetary allowance to their party - for example, where they surrender a member of their personal staff to the central party for an individual task, project or set period. While this is a rare occurrence within large, well-staffed parties, newly formed and minor parties with little in the way of staffing and resources often call on members to help them in such ways.

Resources allocated to parliamentary parties, as opposed to resources allocated to parliamentarians, introduce a new variable into the parliamentary dynamic as they create a separate space for the legislative party to function in parliament in its own right. As a result, instead of a legislative party's ability to operate depending solely on its ability to appropriate or pool resources allocated to members on an individual basis - such as the tithing of members', office-holders' or ministers' salaries and the pooling of print, communications and graphic design allowances ${ }^{25}$ - this separate layer of parliamentary support entitles parties to resources in their own right. One interesting feature of this support is that it is provided in addition to the sum of available pooled resources, which means that qualifying parties gain additional resources simply by virtue of attaining the status of a parliamentary party. This perhaps supports Bowler's description of such resources as constituting 'material rewards', as, in effect, they constitute an institutional reward for parties. ${ }^{26}$

It must be acknowledged that legislative parties and their members are not the only ones who profit from the provision of this support for tools of the trade. Parliament itself benefits substantially from parliamentary parties having the capacity to operate cohesively and effectively. Nevertheless, this important function is somewhat undermined by the differential level at which support is provided to different party groups, how it is allocated and how it is overseen.

25 Bolleyer and Gauja, 'Parliamentary Salaries as a Party Resource'; Bolleyer and Gauja, 'The Limits of Regulation'.

26 Shaun Bowler (2000) 'Parties in Legislatures: Two Competing Explanations', in Russell J. Dalton and Martin P. Wattenberg (eds) Parties without Partisans: Political Change in Advanced Industrial Democracies, Oxford: Oxford University Press, pp. 157-79. 


\section{Allocating and overseeing the provision of tools-of-trade resources}

The authority to set the level of parliamentary allowances and to determine the ways in which these allowances are distributed originates and rests with parliamentarians themselves. ${ }^{27}$ This has its roots in the doctrine of the separation of powers and the principle of maintaining the independence of parliament as a distinct and inviolable organ of the state. ${ }^{28}$ Members of Parliament should not be beholden to external forces for subsistence: to support the basic functioning of the institution, parliament must either directly sign off on the provision of finance and resources for its operation or delegate that responsibility to another authority such as a remuneration tribunal or a ministerial department. ${ }^{29}$ It is important to note, however, that where a body is entrusted with such responsibility, it is on the basis of delegated authority, which leaves it open for parliament to revisit the arrangement at a later time. The rationale for this is to ensure that members are free to discharge their duties without fear of monetary reprisal from vested interests. ${ }^{30}$ For example, members of the US Senate were paid directly by their sending States between 1787 and 1789 until the Constitutional Convention vested Congress itself with authority to pay members. This action was taken in a bid to strengthen central government by providing members with a level of independence from State administrations so they could exercise autonomy in decision-making.

Placing the power to determine salaries and allowances in the hands of parliament itself is therefore sensible in many respects. This is despite the inherent 'paradox' ${ }^{31}$ presented by the fact that those who stand to benefit from parliamentary allowances are the ones who determine who gets what, when and how. ${ }^{32}$ As a means of addressing this shortcoming, the general trend since the 1970s has been to delegate varying levels of authority to independent statutory bodies so that they may make recommendations and determinations, inquire into

27 Wilkinson, MPs' Entitlements.

28 See Seaward, 'Sleaze, Old Corruption and Parliamentary Reform'.

29 Wilkinson, MPs' Entitlements.

30 ibid.

31 Ekaterina Rashkova and Ingrid van Biezen (2014) 'The Legal Regulation of Political Parties: Contesting or Promoting Legitimacy?', International Political Science Review 35(3): 265-74.

32 Belcher Review, p. 47; Wilkinson, MPs' Entitlements, p. 27. 
and oversee salary and allowance allocations. In Australia, this has come in the form of a number of remuneration tribunals. The first of these was the Commonwealth Remuneration Tribunal, which was founded in 1973 following a report by Justice Kerr concerning salary and allowance determination practices. ${ }^{33} \mathrm{Up}$ to this point, decisionmaking had been the sole preserve of parliament and the executive government; indeed, even after its establishment, the Remuneration Tribunal did not fully assume authority over salaries and allowances until 2012. ${ }^{34}$ Between 1990 and 2012, its remit was to provide inquiry and advisory services, which facilitated a more transparent decisionmaking process concerning allowance allocations while leaving ultimate decision-making authority in the hands of parliament and the executive government. In addition to increased transparency, the Remuneration Tribunal provided a forum for parliamentarians to volunteer information on their own experiences of parliamentary life and the resources they wished to see introduced. This resulted in an increase and expansion of resources such as staff allowances in the years following establishment of the tribunal, the result of which were increased costs for parliament, which is ultimately why the responsibilities of the tribunal were curtailed until more recent years. ${ }^{35}$ This general delegated approach was, however, replicated in New South Wales (NSW) and Western Australia in 1975, South Australia (SA) in 1990, the ACT in 1995, the NT in 2001, Queensland in 2013 and Tasmania in 2014. Despite this general move towards systematisation, standardisation and independent oversight of decision-making concerning individual resources, the allocation of legislative party resources continued to be subject to substantially lesser levels of oversight and transparency.

Although office-holders qualifying for access to legislative party toolsof-trade resources tend to be identified in the entitlements handbooks produced by individual parliaments, such texts stop short of setting

33 The Commonwealth Remuneration Tribunal was established through the Remuneration Tribunal Act 1973; the NSW Remuneration Tribunals were established under the Statutory and Other Offices Remuneration Act 1975; Western Australia's Salaries and Allowances Tribunal was established through the Salaries and Allowances Act 1975; the Remuneration Tribunal of South Australia through the Remuneration Act 1990; and the Queensland Independent Remuneration Tribunal was established through the Queensland Independent Remuneration Tribunal Act 2013. Kerr Report.

34 Cathy Madden and Deirdre McKeown (2013) Parliamentary Remuneration and Entitlements, Canberra: Parliament of Australia.

35 Jones, 'One Step at a Time'. 
out the extent of resources that are to be provided. Determinations of this nature are instead left to the premier or prime minister of the jurisdiction in question. This is the case, for example, in relation to resources provided to legislative parties in the Commonwealth Parliament, where 'convention's6 dictates that, subject to his or her discretion, the prime minister may allocate one additional staff member to minor parties consisting of fewer than five serving members. Each leader of a minor party holding parliamentary party status - that is, those meeting or exceeding the five serving member thresholdis provided with a substantially more generous complement of staff. The Greens, for example, were allocated 13 positions in 2010. Additional staffing for the opposition is greater again, conventionally set at 21 per cent of the allocation for the government. In 2010 this meant 420 additional positions for the government and 88 for the opposition..$^{37}$ In announcing the 2010 allocation of additional staff, the Special Minister of State argued:

It is obvious that the current political environment is a challenging one. It is important the Government, Opposition, Minor Parties and independents are able to access advice and prepare and facilitate negotiated outcomes to serve the Parliament and the people in an efficient and effective way. ${ }^{38}$

These additional staff positions are provided in a bloc to the Leader of the Opposition or the leader of a minor party, who can then reallocate them at his or her discretion.

State-level parliaments operate under similar arrangements. The Leader of the Opposition in the Queensland State Parliament, for example, receives tools-of-trade resources subject to an application to and approval by the State premier. In this case, levels of staffing and resources are not established or set, but rather are subject to negotiation and interpretation. Importantly, the Leader of the Opposition must make a specific request for the number of staff they require and the premier may then grant or deny that request. This of course opens up

36 Tony Abbott MP (2013) Official press conference, 17 September, Brunei, available at: pm.gov.au/media/2013-10-10/press-conference-brunei.

37 The number of personal positions allocated to the government had reached 467.9 in 2007, but had been cut back by the incoming Labor Government.

38 Gary Gray, AO, MP (2010) 'Media Release: Ministerial and Parliamentary Staffing to Increase', 28 September, Canberra, available at: parlinfo.aph.gov.au/parlInfo/search/display/ display.w3p;query\%3DId\%3A\%22media \%2Fpressrel\%2F328953\%22. 
the practice of bargaining, which is an important aspect of this form of allowance, the full extent to which it plays a part becoming most apparent when we look to the fringes of legislative party resource provision-namely, the process by which parties that qualify for reduced resources, or none at all, attempt to acquire them.

\section{Discretion and bargaining in the allocation of tools of trade}

An example of bargaining in relation to tools-of-trade resources can be found in the prominent agreements made by the Australian Labor Party (ALP) when trying to form the government of the 43rd Parliament in 2010. One concession made to crossbench MPs holding the balance of power was to provide them with additional personal staff in exchange for pledges of support on matters of 'confidence and supply' ${ }^{39}$ This resulted in the lower house Greens MP Andrew Bandt and Independents Tony Windsor, Rob Oakeshott, Andrew Wilkie and Bob Katter each being allocated a personal staff of two in addition to the standard four electorate staff. ${ }^{40}$ In contrast, Senators John Madigan and Nick Xenophon (a minor party Senator and Independent Senator, respectively), who did not factor in the Senate balance of power, received only one personal staffing position each in the 43rd Parliament. The 44th Parliament saw a reversal of this situation when the Independents and The Greens no longer held the balance of power in the House of Representatives. Subsequently, their personal staff allowances were reduced to one each, while the crossbench Senators, who now held the balance of power, were each allocated two personal staff positions (see Chapter 1, Table 1.3).

A further example can be seen in Clive Palmer's formal request on 4 June 2014 that the Palmer United Party (PUP) be designated as a parliamentary party and for staffing numbers to be provided in line with those received by The Greens. Palmer argued:

39 Julia Gillard MP (2010) 'Letter Confirming Acceptance of Agreement to Support ALP Government', Canberra, available at: tonywindsor.com.au/releases/AgreementToFormGovt.pdf. 40 'The Australian Labor Party and the Independent Members (Mr Tony Windsor and Mr Rob Oakeshott) ("the parties") —Agreement', 7 September 2010, available at: resources.news.com.au/ files/2010/09/07/1225915/542989-final-agreement-with-the-independents.pdf. 
If we don't get any resources you can well imagine it will take longer for the three people to do their job and maybe you'll only get one bill through a year. ${ }^{41}$

With three incoming Senators and a seat in the House of Representatives, the PUP was one seat short of eligibility for parliamentary party status. This remained the case despite efforts to have the party's voting pact with Senator Ricky Muir of the Motoring Enthusiast Party acknowledged to make up the shortfall. ${ }^{42}$ While receiving a degree of publicity at the time, the attempt to gain parliamentary party status was ultimately a fruitless endeavour, which may be explained by the PUP's reduced bargaining position within a record 18-strong Senate crossbench.

Although Palmer's prediction of a one bill per annum work rate may have somewhat exaggerated the level of obstruction caused by the under-resourcing of the PUP, members do require adequate staffing to ensure they have sufficient capacity to give due consideration to the full range of legislation and other business before either house.

Family First Senator Bob Day and Independent Senators Nick Xenophon and John Madigan also concurred with the need for increased staffing when asked to comment on Palmer's request, although they differed on how this might be achieved. ${ }^{43}$ While Madigan and Xenophon indicated a need for increased individual staffing allowances, Senator Day suggested that a 'crossbench secretariat' could be a workable solution. ${ }^{44}$ Nevertheless, there was uniformity in the calls made for increased resources, and this perhaps indicates the need for some form of review aimed at assessing the adequacy of resources provided to these crossbench members and those in comparable situations.

This situation has not changed significantly over the past two decades. In 1996, Bob Brown expressed similar sentiments when The Greens had two Senators and fell below the parliamentary party threshold.

41 Bob Brown speaking on The Senate: What Goes Around Comes Around (5 May 1996), ABC Radio, Canberra, available at: abc.net.au/radionational/programs/backgroundbriefing/thesenate-what-goes-around-comes-around/3563852\#transcript.

42 Lenore Taylor (2014) 'Clive Palmer Fights for Parliamentary Resources Boom but Still No Reply', The Guardian, 24 April.

43 John Madigan was a member of the Democratic Labour Party until he resigned to become an Independent in September 2013.

44 Taylor, 'Clive Palmer Fights for Parliamentary Resources Boom but Still No Reply'. 
This was in contrast with the Australian Democrats, who had seven members and designated parliamentary party status. Speaking of the negotiations surrounding the formation of the Howard Government in 1996, Senator Brown stated:

I expected to have a staff establishment which would be equal to the job ... we have to deal with the full range of legislative initiatives coming into the Senate, same as the House of Reps ... and you need the wherewithal to know what the legislation is that you're dealing with, otherwise you vote No. And it doesn't get through, and the load can build up. ${ }^{45}$

Brown also, however, highlighted the difficulty the current resource allocation regime creates for minor parties and Independents:

People are normally shy about talking about the need for staffing the job that they're doing because it leads so easily to media condemnation or scurrying about with the view that here's somebody who's trying to increase their own bailiwick. ${ }^{46}$

The latter point, in particular, highlights the problematic nature of the power dynamic that this discretionary mode of allocation creates. Larger parties are automatically allocated relatively large levels of resources, which means this form of resource access is rarely spoken of. However, Independents and minor party actors, who must negotiate to achieve modest increases in the resources available to them, must weigh up the benefits against the potentially negative publicity that can accompany such requests. Those placed in the position of having to raise their heads above the parapet to advocate for additional party resources do so at the risk of bearing the brunt of 'public disquiet' concerning political entitlements and state subvention of politics. ${ }^{47}$ Disquiet of this nature can reach fever pitch at times of financial hardship or when scandals emerge concerning the misuse of parliamentary allowances, and this can create a reluctance to press the issue.

On the other hand, failing to do so can also result in negative public relations outcomes. That is because additional staff allow parliamentarians to deal more effectively with the substantial

\footnotetext{
45 Brown, in The Senate.

46 ibid.

47 Timothy John Abey (Chair), Nicole Mary Wells and Barbara Deegan (2014) Report of the Parliamentary Salaries and Allowances Tribunal Inquiring into Basic Salary, Allowances and Benefits Provided to Members of the Tasmanian Parliament, Hobart: Parliament of Tasmania, p. 2.
} 
workloads that come their way. This alone can impact positively on a legislator's reputation among fellow parliamentarians and, vitally, among the press gallery. However, the effect can go further. A hugely important part of any parliamentarian's job is to communicate what they have achieved in office to their electorate. Publicity of this sort, however, rarely arises spontaneously and is generally the product of long hours spent courting members of the press, distributing press releases and publicity materials, cultivating an online presence and, vitally, working with constituents on issues of importance. Additional staffing provides breathing space for this work and, by extension, has the potential to bolster the re-election prospects of members down the line.

\section{Issues arising from the discretionary allocation of resources}

There is a place for discretion in the allocation of resources, particularly when it comes to how they are deployed within parties. For example, when allocated additional personal staff under this scheme, the leader of a party may, at their discretion, redeploy them to party colleagues. This is important as it ensures that parties have relative freedom to decide how to make the best use of the collective resources available to them. Intraparty distribution aside, however, the wisdom of making the overall allocation of such resources a matter of discretion is questionable.

One downside is that discretionary authority of this sort may be used to pressure minor parliamentary actors into lending support to government or it may have the effect of marginalising those of little relevance to the government formation process. Those refusing, or unable, to engage in bargaining have the potential to be left at a substantial disadvantage compared with parliamentary colleagues who automatically qualify for party-based tools-of-trade resources or broker deals of their own. While this is simply an extension of the political dynamics that arise from the electoral process - and it may be argued that those choosing not to trade support for resources have only themselves to blame - the use of taxpayer-funded resources for such political purposes is problematic. 
It is, first, not consistent with the spirit of resource allocation as originally intended: a mechanism to promote the principles of equal franchise, equal mandate and equal access to democratic politics by ensuring that each vote and member is regarded with equal value, and parliamentarians are provided with equal tools with which to do the job. The track record of tools-of-trade resources being used as rewards for those lending support to government demonstrates how something as seemingly innocuous as staffing, office space and ICT can become politicised. And it appears that the discretionary basis of allocations has contributed to this shift away from the principle of uniform access towards a more politically motivated form of provision. This goes against the spirit of the public subvention of politics, the ultimate purpose of which is to level the playing field.

This mode of allocation also calls into question the neutrality of parliamentary institutions. Where differential levels of resources are provided on the basis of affiliation and bargaining power, as distinct from an objective assessment of need, the institutions of parliament can be seen as encouraging certain forms of affiliation and behaviour while discouraging others. When considered in this light, these institutions may more accurately be classified as incentive structures, as they reward behaviour consistent with the preferences of the decision-makers determining resource allocations. What makes this problematic is that taxpayer-funded resources provided to support the operation of parliament are appropriated and used for political ends. Parallels can be drawn between this situation and that of the earlier example of the Liberal Speaker of the House of Representatives, Bronwyn Bishop, using her parliamentary travel entitlements to attend a Liberal Party fundraiser. This time, however, the entitlements are not the only things being used for political purposes, but the very institutional structures through which they are allocated. Yet, to date, little attention has been paid to the prominent role of discretion and bargaining in the resource allocation mechanism.

The way tools-of-trade resources are allocated presents a barrier to achieving greater levels of transparency in the area of parliamentary resource and allowance provision more generally. This is not simply due to the lack of standards and guidelines to be referred to when identifying the levels of resources allocated to different groupingsalthough these issues do make identifying levels of resource access rather difficult. A worrying by-product of this mechanism is that 
it appears to curtail discussion surrounding this form of resource support and the mode by which allocations are made. There is a reticence among those who stand to benefit most from a change to the regime to speak of these resources, as indicated by Bob Brown's statements on the matter. For one thing, doing so has the potential to damage current or future levels of resource access as members criticising the system are effectively biting the hand that feeds them. This could sully political relationships and close off resource access into the future. Fear of reprisal from the public for raising the issue is also a real concern - again, highlighted by Brown. In this respect, Tucker has it right. There is a highly negative attitude among the public towards providing even the most modest supports for politicians. The very idea of individuals presenting themselves to their premier and asking 'please sir, I'd like some more' is a risk that must be weighed against the potential benefits of the additional resources and, of course, the risk of having the request rejected. Politically speaking, this places Independents and smaller parties at a strategic disadvantage to their peers who belong to larger parties.

\section{Conclusions}

In the Australian context, the extent to which the prime minister or premier has power to allocate parliamentary resources creates a level of uncertainty for recipients. Access to resources is a moveable feast, particularly for those who must negotiate with government to gain staffing allocations. This can result in increased resources for individual parliamentarians and legislative parties that enter into positive relationships with the government or in reduced resources for those reluctant to lend such support or with little bargaining power. As such, while access to these resources in part turns on electorally determined factors such as party strength, the needs of the government play a key role. This, in turn, creates a level of uncertainty felt most acutely by those most dependent on the discretion of government for receipt of these allowances - that is, those parties hovering around the threshold of parliamentary party status and Independents. 
This power dynamic illustrates how parliamentary resources may be allocated by the prime minister to achieve political ends, by virtue of the lack of formal regulation in this area. ${ }^{48}$ Access to resources is governed by the extent to which minor party actors factor in the balance of power and their willingness to trade support to obtain them. This begs the question of whether it is desirable that government be given such freedom to leverage capacity-building resources for political gain. It also brings into question the ability of newly emerging political alternatives to challenge the status quo. Once having achieved parliamentary breakthrough, political actors falling into this category who fail to win enough seats to attain parliamentary party status are faced with the choice of either negotiating with government for additional resources or operating at a disadvantage to those they seek to oppose. By placing minor parties and Independents on a more precarious footing when it comes to resource provision, the principle of equal representation is undermined.

One way of addressing this issue - in addition to limiting discretion and standardising entitlements in this area - may be to reconsider the link between resource entitlements and the criteria used to determine whether a party acquires parliamentary party status. While it aids procedural clarity to set out what does and does not constitute a parliamentary party, the necessity of applying the same criteria in determining who qualifies for additional tools-of-trade resources is questionable. Precedent exists in other jurisdictions for disaggregating the two and this may be a useful line of inquiry in the Australian context. For example, Irish political parties seeking parliamentary group status must have a minimum of five members elected to the Dáil Éireann (lower house).$^{49}$ Having attained this status, these groups are entitled to procedural privileges such as a guaranteed portion of all speaking time, priority questions to ministers, a place at leaders' questions and a role in determining the items discussed during private members' time. ${ }^{50}$ Lack of group status does not, however, disqualify minor parties or Independents from resources

\footnotetext{
48 Senator Evans speaking at the Senate Finance and Public Administration Legislation Committee (13 February 2006), Parliament of Australia, Canberra.

49 Prior to a 2016 reform, this qualification was set at seven.

50 Standing Orders of Dáil Éireann Relative to Public Business (2011), Dublin: Oireachtas Éireann.
} 
such as the monetary PAA. ${ }^{51}$ Each party with a minimum of one member elected to either the lower or the upper house is entitled to an automatic complement of party staff, office space, equipment and financial allowance proportionate to its number. Moreover, allocations are made using a defined mathematical formula that takes account of party strength rather than the negotiating position of parliamentary actors. ${ }^{52}$ While the Irish system is by no means perfect and efforts at reform were ongoing at the time of writing, its practice of divorcing a certain level of resource access from parliamentary group status may be worth considering in the Australian context given the issues highlighted here.

Another aspect of this scheme that would benefit from further review is the effect the allocations mechanism has on the behaviour and re-election prospects of legislators. ${ }^{53}$ It is anticipated that if such an effect is present it is likely to manifest both directly and indirectly, although further investigation would be helpful in confirming or rebutting this. In a direct sense, those parliamentarians belonging to legislative parties qualifying for such rewards may be better equipped to make use of policymaking and participation opportunities. Moreover, when it comes to election time, these members have increased levels of resources available to drive their campaigns. As a result, the indirect effect is that these members may be perceived as more capable, effective and organised than Independents or those aligned to minor parties, who either do not benefit from such resources or receive reduced levels. This has the potential to generate a positive feedback loop whereby such perceived superiority leads to improved electoral performance, which in turn leads to larger resource allocations. Admittedly, quantifying this indirect effect would be challenging in light of the multitude of variables that contributes to electoral outcomes. There is, however, an established literature that highlights the electoral advantage that accompanies incumbency ${ }^{54}$ and

51 Although it must be noted that reduced allocations are made only to Independents - a grievance for that category of parliamentarian.

52 Oireachtas (Ministerial and Parliamentary Offices) (Secretarial Facilities) Regulations 2013 (No. 2 of 2013), Ireland.

53 Simon Hix (1998) 'Elections, Parties and Institutional Design: A Comparative Perspective on European Union Democracy', West European Politics 21(3): 19-52.

54 Joel W. Johnson (2012) 'Campaign Spending in Proportional Electoral Systems: Incumbents Versus Challengers Revisited’, Comparative Political Studies 46(8): 968-93. 
also the advantages of appearing to come from outside the political class. As such, this issue may merit consideration within the context of these areas of scholarship.

Finally, an overt dependence on informal 'convention' as the guiding hand in parliamentary party resource allocation creates a barrier to transparency. This is compounded by the lack of formal review and appeal mechanisms, which in turn creates difficulties in measuring the extent of resource access among parliamentarians and in identifying allocation patterns both within and across parliamentary terms. Those parliamentarians operating outside parties with recognised parliamentary party status appear to experience significant uncertainty regarding the levels of access to parliamentary resources and the extent to which they may fluctuate from parliamentary term to parliamentary term. Granted, uncertainty is part of parliamentary life in that each election brings with it the prospect of seat loss and resulting job losses for staff. Yet this uncertainty is compounded for those whose access to key resources is precarious by virtue of their party affiliation. Whether they are liked or loathed, as long as Independents and minor parties win election to parliament through free and fair elections, an argument can be made for their entitlement to equal levels of resource access relative to their parliamentary colleagues. Unfortunately, the present system does not guarantee this and, as such, it merits examination and reform. It is therefore hoped that by shedding a little light on the issue, this chapter may prompt policymakers to consider a review of these practices so they may be brought into line with other forms of resource allocation. It is anticipated that this would go some way to addressing the need for transparency, certainty and consistency in this area of parliamentary life. 
This text is taken from Party Rules?: Dilemmas of political party regulation in Australia, edited by Anika Gauja and Marian Sawer, published 2016 by ANU Press, The Australian National University,

Canberra, Australia. 